\title{
Gender difference in the development of cardiac lesions following acute ischemic-reperfusion renal injury in albino rats
}

\author{
Ibrahim Y. Ibrahim, Eman A. Elbassuoni, Merhan M. Ragy and Wagdy N. Habeeb \\ Physiology Department, Minia University School of Medicine, Minia, Egypt
}

\begin{abstract}
Renal ischemia-reperfusion (I/R) is the major cause of acute renal failure. Renal I/R have distant effects on other organs, especially the heart. The purpose of this study was to investigate cardiac lesion following bilateral renal ischemia (50 minutes) and reperfusion (48 hours) in adult rats, to test sex differences in the development of cardiac lesions after acute renal $\mathrm{I} / \mathrm{R}$ and to investigate the effect of estrogen on this type of cardiac lesions. 70 adult albino rats were divided into 7 groups: control male, I/R male, control female, I/R female, female with bilateral ovariectomy, I/R female with bilateral ovariectomy and I/R female with bilateral ovariectomy treated with estrogen. Renal and cardiac functions in both sexes were deteriorated following acute renal I/R injury proved by the increase in serum urea, creatinine, lactate dehydrogenase and creatine kinase levels. These cardiac lesions are mainly due to the oxidative stress response in the form of the increase in cardiac tissue lipid peroxide, and the decrease in cardiac tissue glutathione reductase, superoxide dismutase and catalase levels. In conclusion, female rats are more protected from the renal and cardiac lesions following acute renal I/R injury than male, since estrogen significantly decreases these lesions mainly by inhibiting the oxidative stress response.
\end{abstract}

Key words: Renal - Ischemia-reperfusion - Cardiac lesions

\begin{abstract}
Abbreviations: ARF, acute renal failure; CAT, catalase; CK, creatine kinase; CVS, cardiovascular system; ERK, extracellular signal-related kinase; GR, glutathione reductase; IL, interleukin; I/R, ischemia-reperfusion; $\mathrm{K}_{\mathrm{ATB}}$ ATP-sensitive potassium channel; $\mathrm{LDH}$, lactate dehydrogenase; $\mathrm{LPO}$, lipid peroxide; MAPK, mitogen-activated protein kinase; MDA, malondialdehyde; MPO, cardiac myeloperoxidase; NAD, nicotinamide adenine dinucleotide; Ovx, ovariectomy; SOD, superoxide dismutase; TNF- $\alpha$, tumor necrosis factor- $\alpha$.
\end{abstract}

\section{Introduction}

Ischemia-reperfusion (I/R) injury is a complex phenomenon often encountered in surgical practice. The consequences of such injury are local and remote tissue destruction, and sometimes death (Sirotković-Skerlev et al. 2006). Ischemia means inadequate blood supply to the tissues, while reperfusion refers to restoration of blood flow to these ischemic tissues (Shivanand 2010).

Renal I/R injury occurs in various clinical settings including severe hypotension and subsequent resuscitation,

Correspondence to: Eman A. Elbassuoni, Physiology Department, Minia University School of Medicine, Minia, Egypt

E-mail: emanelbassuoni@yahoo.com shock, sepsis, renal transplantation, and aorto-vascular surgery. The mortality rates for intensive care unit patients with acute renal ischemia range between $30 \%$ and $70 \%$. Clinically, it has become apparent that most of the high patient mortality can be attributed to the onset of systemic inflammatory response syndrome and progression to multiple organ failure, e.g. heart, liver and brain (White and Hassoun 2012).

Acute renal failure (ARF) usually results in significant morbidity and mortality, yet ARF is not the usual cause of death clinically. Bilateral renal ischemia affects the other organs, especially the heart; many studies on uremic patients have shown that heart failure is one of the major causes of death in these patients. However, the pathophysiology of cardiac dysfunction in ARF remains unclear (Kelly 2003). 
Gender differences in the occurrence and progression of renal diseases are reported by Kehr et al. (2005) and Metcalfe and Meldrum (2006) in acute and chronic ischemic renal failure and by Neugarten (2002) in renal diseases with diabetes. Cardiovascular system (CVS) in males and females also differs significantly in many parameters under both physiological and pathological conditions. Detailed cellular and molecular mechanisms of these differences are still unknown, they involve genomic and non-genomic effects of sex hormones, particularly estrogen (Ostadal et al. 2009).

Female gender is known to be protected against $I / R$ injury of several organs, the protective effects of estrogen may contribute to these differences. Estradiol administration attenuates renal, myocardial, cerebral, hepatocellular and splanchnic I/R injury (Robert et al. 2011).

The present study was conducted on a trial to: (1) Investigate cardiac lesions following bilateral renal ischemia (50 minutes) and reperfusion (48 hours) injury in adult male and female rats, (2) Test whether there is a sex difference in the development of the above cardiac lesions and (3) Investigate the effect of estrogen on this type of cardiac lesions.

\section{Materials and Methods}

\section{Ethical approval}

Minia University School of Medicine ethics committee, the local ethics committee in our university, approved this animal experiment protocol, and it is carried out in accordance with the NIH guidelines.

\section{Experimental groups and animals}

A total of 70 adults, 8-10 weeks, Sprague-Dawley albino rats (20 males and 50 females) weighing between 200-250 g were used throughout the present study. Rats were housed at room temperature with 12 hour light/dark cycle with a supply of a standard diet of commercial rat chow and water ad libitum. Animals were left to acclimatize to the environment for two weeks prior to inclusion in the experiment. The rats were divided into 7 different groups $(n=10)$. Group 1: Control sham-operated male rats (underwent all surgical procedures without I/R in normal rats); group 2: male rats with bilateral renal I/R; ischemia was produced for $50 \mathrm{~min}$, followed by $48 \mathrm{~h}$ reperfusion; group 3: control sham-operated female rats (underwent all surgical procedures without I/R or ovariectomy); group 4: female rats with bilateral ovariectomy (Ovx); group 5: female rats with bilateral renal $\mathrm{I} / \mathrm{R}$ (I/R); ischemia was produced for $50 \mathrm{~min}$, followed by $48 \mathrm{~h}$ reperfusion; group 6: female rats with bilateral renal $\mathrm{I} / \mathrm{R}$ done 4 weeks after bilateral ovariectomy $(\mathrm{Ovx}+\mathrm{I} / \mathrm{R})$; group 7: female rats with bilateral renal I/R done 4 weeks after bilateral ovariectomy treated with estrogen supplementation $(25 \mu \mathrm{g} / \mathrm{kg} /$ day; SC) for 3 weeks starting 1 week after the ovariectomy $(\mathrm{Ovx}+\mathrm{E}+\mathrm{I} / \mathrm{R})$ (Yu et al. 2009)

\section{Chemicals}

Estrogen in the form of Folone ampoules, each $1 \mathrm{ml} \mathrm{am-}$ poule contains $5 \mathrm{mg}$ estradiol benzoate in oily solution, was purchased from Misr Co. for pharm. ind. S.A.E. (Cairo, Egypt). Sesame oil was purchased from Indian Co. (Cairo, Egypt). Thiopental sodium was purchased from Eipico Co. (Cairo, Egypt). Ether $\left(\mathrm{C}_{4} \mathrm{H}_{10} \mathrm{O}\right)$ was purchased from Alpha Chemical Co. (Mumbai, India). Phosphate buffered saline (PBS) was purchased from Oxford Co. (Mumbai, India); each capsule was dissolved in $100 \mathrm{ml}$ distilled water to give a buffer of pH 7. Triton X-100 (t-octylphenoxy-polyethoxyethanol) and trichloroacetic acid (TCA; $\mathrm{C}_{2} \mathrm{HCl}_{3} \mathrm{O}_{2}$ ) were purchased from Sigma-Aldrich (Steinheim, Germany). Kits for measuring blood urea, serum creatinine, and serum lactate dehydrogenase were purchased from Diamond Diagnostics (Cairo, Egypt). Kits for measuring serum creatine kinase, cardiac tissue lipid peroxide, cardiac tissue glutathione reductase, cardiac tissue superoxide dismutase, and cardiac tissue catalase were purchased from Bio-Diagnostic (Cairo, Egypt).

\section{Renal I/R animal model}

The rat was anesthetized by intraperitoneal injection with thiopental sodium (30-50 mg/kg of $1 \%$ solution). The anesthetized rat was placed on a heating pad to maintain the rectal temperature constant $\left(37^{\circ} \mathrm{C}\right)$ throughout the surgery. $2 \mathrm{~cm}$ long longitudinal abdominal midline incision was made just below the sternum by a scalpel blade. Both kidneys were exposed; bilateral renal ischemia was induced by non-traumatic surgical clamps over the pedicles (arteries and veins) of the two kidneys for 50 minutes. Following the occlusion, the occurrence of ischemia was visually confirmed by the observation of renal blanching. During the period of ischemia, the edges of the abdominal incision were approximated to each other, and covered by a cotton pad soaked in warm isotonic saline $\left(37^{\circ} \mathrm{C}\right)$ to prevent the undue loss of body fluids. After removal of the clamps, the kidneys were observed for an additional 1 minute to ensure renal reperfusion (blood reflow) indicated by the color changes. The incision was then closed using a sterile $2 / 0$ suture. Renal reperfusion was allowed for $48 \mathrm{~h}$ (Kelly 2003). In sham-operated group, the same surgical procedures were done but without applying the clamps.

\section{Ovariectomized rat model}

The rat was anesthetized by ether inhalation. The anesthetized rat was placed on the operating board in dorsal recum- 
bence with its tail directed towards the surgeon. The ventral aspect of the lumbar region was shaved, and then cleaned with $75 \%$ ethanol, followed by thorough scrubbing with $10 \%$ povidone iodine (Betadine). $1 \mathrm{~cm}$ long longitudinal ventral midline incision was made above the symphysis pubis by a scalpel blade; the skin edges were laterally retracted, and the abdominal muscle layer and the peritoneum were incised. Both fallopian tubes were exposed and ligated; the ovary can usually be seen embedded in a pad of fat in the abdomen; then the ovaries were removed by cutting them with scissors, taking care not to rupture the ovarian capsules. The remaining tissues were replaced into the peritoneal cavity. The incision was then closed using a sterile $2 / 0$ suture. The removed tissue was ensured to be the ovaries by histological sections (Flores et al. 2008).

\section{Animal sacrifice and sample collection}

The rats were sacrificed by decapitation. The blood samples were immediately collected in $10 \mathrm{ml}$ Eppendorf tubes, allowed to clot, and then delivered into centrifuge tubes to be centrifuged at $3.000 \mathrm{rpm}$ for 20 minutes; serum samples were separated in $2 \mathrm{ml}$ Eppendorf tubes to be used immediately as fresh samples (preferred) or to be stored at $-20^{\circ} \mathrm{C}$ until used. The hearts of the rats were dissected and stored at $-80^{\circ} \mathrm{C}$ until used. Serum samples were used to determine urea, creatinine, lactate dehydrogenase (LDH), and creatine kinase (CK) levels, while cardiac samples were used to determine lipid peroxide (LPO), glutathione reductase (GR), superoxide dismutase (SOD), and catalase (CAT) levels.

\section{Parameters measured}

At the end of the experimental protocol, the following parameters were measured: blood urea by Berthelot enzymatic colorimetric method (Young 2001), serum creatinine by Jaffé calorimetric-end point method (Young 2001), serum LDH by kinetic method (Rechsteiner 1970), serum CK by kinetic method (Moren 1977), cardiac tissue LPO - malondialdehyde (MDA) - by colorimetric method (Ohkawa et al. 1979), cardiac tissue antioxidant enzymes: GR by UV method (Goldberg and Spooner 1983), SOD by colorimetric method (Nishikimi 1972), CAT by colorimetric method (Aebi 1984).

\section{Statistical analysis}

All values are presented as means \pm SEM. Statistical significance was tested between more than two groups using oneway ANOVA test. Analyses were performed using statistical software (SPSS version 11.0; Chicago, IL, USA). Significance for all analysis was accepted as $p \leq 0.05$.

\section{Results}

Effect of renal $I / R$ injury on renal and cardiac injury markers in male and female rats

Renal injury markers, blood urea and serum creatinine, were significantly higher in I/R male and I/R female groups than that in control male and control female groups, respectively. Cardiac injury markers, serum LDH, serum CK and cardiac tissue LPO, were significantly higher, while cardiac tissue antioxidant enzymes, GR, SOD and CAT, were significantly lower in I/R male and $\mathrm{I} / \mathrm{R}$ female groups than that in control male and control female groups, respectively (Table 1,2 ). This indicates that the heart is subjected to oxidative stress injury following acute renal I/R injury.

Table 1. Effect of renal I/R injury on some renal injury markers, and cardiac injury markers in male rats

\begin{tabular}{|c|c|c|c|c|}
\hline Parameter & & & Control males & $\mathrm{I} / \mathrm{R}$ males \\
\hline \multirow{2}{*}{ Renal injury markers } & \multirow{2}{*}{ In blood } & Urea (mmol/l) & $6.4 \pm 0.2$ & $66.3 \pm 1.7^{* *}$ \\
\hline & & Creatinine $(\mu \mathrm{mol} / \mathrm{l})$ & $65.4 \pm 1.8$ & $617.0 \pm 13.3^{* *}$ \\
\hline \multirow{6}{*}{ Cardiac injury markers } & \multirow{2}{*}{ In blood } & $\mathrm{LDH}(\mathrm{U} / \mathrm{l})$ & $668.5 \pm 11.3$ & $1245.0 \pm 15.7^{\star *}$ \\
\hline & & $\mathrm{CK}(\mathrm{U} / \mathrm{l})$ & $18.2 \pm 0.5$ & $36.2 \pm 1.1^{* *}$ \\
\hline & \multirow{4}{*}{ In cardiac tissue } & LPO (U/g) & $75.7 \pm 0.6$ & $97.7 \pm 0.7^{\star \star}$ \\
\hline & & GR (U/g) & $0.40 \pm 0.01$ & $0.20 \pm 0.01^{\star *}$ \\
\hline & & SOD (U/g) & $22.0 \pm 0.4$ & $9.1 \pm 0.2^{\star *}$ \\
\hline & & CAT (U/g) & $0.90 \pm 0.02$ & $0.40 \pm 0.02^{* *}$ \\
\hline
\end{tabular}

Values are means \pm SEM. ${ }^{* *} p<0.01$ significant difference from control males; $n=6 . n$, number of rats in each group; I/R, ischemia reperfusion; LDH, lactate dehydrogenase; CK, creatine kinase; LPO, lipid peroxide; GR, glutathione reductase; SOD, superoxide dismutase; CAT, catalase. 
Table 2. Effect of renal I/R, ovariectomy and estrogen replacement on some renal injury markers, and cardiac injury markers in female rats

\begin{tabular}{|c|c|c|c|c|c|c|c|}
\hline Parameter & & & $\begin{array}{l}\text { Control } \\
\text { females }\end{array}$ & I/R females & Ovx & $\mathrm{Ovx}+\mathrm{I} / \mathrm{R}$ & $\mathrm{Ovx}+\mathrm{E}+\mathrm{I} / \mathrm{R}$ \\
\hline \multirow{2}{*}{ Renal injury markers } & \multirow{2}{*}{ In blood } & Urea (mmol/l) & $5.9 \pm 0.1$ & $33.4 \pm 0.7^{\mathrm{a}}$ & $6.1 \pm 0.03$ & $59 \pm 0.8^{\mathrm{b}, \mathrm{c}}$ & $24.3 \pm 0.4^{\mathrm{d}}$ \\
\hline & & Creatinine $(\mu \mathrm{mol} / \mathrm{l})$ & $51.3 \pm 1.8$ & $404.9 \pm 23^{\mathrm{a}}$ & $53 \pm 1.8$ & $558.7 \pm 12.4^{\mathrm{b}, \mathrm{c}}$ & $254.6 \pm 12.4^{\mathrm{d}}$ \\
\hline \multirow{6}{*}{ Cardiac injury markers } & \multirow{2}{*}{ In blood } & $\mathrm{LDH}(\mathrm{U} / \mathrm{l})$ & $416.6 \pm 5$ & $941.3 \pm 13.4^{\mathrm{a}}$ & $854 \pm 20.4^{\mathrm{a}}$ & $1125.4 \pm 8.1^{\mathrm{b}, \mathrm{c}}$ & $946.5 \pm 13.2^{\mathrm{d}}$ \\
\hline & & $\mathrm{CK}(\mathrm{U} / \mathrm{l})$ & $11.7 \pm 0.6$ & $24.9 \pm 0.7^{\mathrm{a}}$ & $18.3 \pm 0.7^{\mathrm{a}}$ & $31.9 \pm 0.8^{\mathrm{b}, \mathrm{c}}$ & $24.3 \pm 0.7^{\mathrm{d}}$ \\
\hline & \multirow{4}{*}{$\begin{array}{l}\text { In cardiac } \\
\text { tissue }\end{array}$} & LPO (U/g) & $65.6 \pm 0.5$ & $81.9 \pm 0.4^{\mathrm{a}}$ & $79.5 \pm 0.9^{\mathrm{a}}$ & $92.2 \pm 0.7^{b, c}$ & $79.1 \pm 0.4^{\mathrm{d}}$ \\
\hline & & GR (U/g) & $0.6 \pm 0.01$ & $0.3 \pm 0.01^{\mathrm{a}}$ & $0.3 \pm 0.01^{\mathrm{a}}$ & $0.2 \pm 0.01^{\mathrm{b}, \mathrm{c}}$ & $0.3 \pm 0.01^{\mathrm{d}}$ \\
\hline & & SOD (U/g) & $32.3 \pm 0.5$ & $15.8 \pm 0.2^{\mathrm{a}}$ & $12.9 \pm 0.4^{\mathrm{a}}$ & $8.3 \pm 0.3^{b, c}$ & $16.4 \pm 0.4^{\mathrm{d}}$ \\
\hline & & CAT (U/g) & $1.6 \pm 0.1$ & $0.8 \pm 0.01^{\mathrm{a}}$ & $0.7 \pm 0.02^{\mathrm{a}}$ & $0.5 \pm 0.02^{\mathrm{b}, \mathrm{c}}$ & $0.8 \pm 0.01^{\mathrm{d}}$ \\
\hline
\end{tabular}

Values are means \pm SEM. ${ }^{\mathrm{a}} p<0.05$ significant difference from control females; ${ }^{\mathrm{b}} p<0.05$ significant difference from I/R females; ${ }^{\mathrm{c}} p<$ 0.05 significant difference from Ovx females; ${ }^{\mathrm{d}} p<0.05$ significant difference from Ovx+I/R females; $n=6 . n$, number of rats in each group, I/R: ischemia reperfusion, Ovx, ovariectomy; E, estrogen; LDH, lactate dehydrogenase; CK, creatine kinase; LPO, lipid peroxide; GR, glutathione reductase; SOD, superoxide dismutase; CAT, catalase.

Effect of ovariectomy and estrogen replacement on renal and cardiac injury markers in female rats

Blood urea and serum creatinine were not statistically significant between Ovx and control female groups. However, they were significantly higher in $\mathrm{Ovx}+\mathrm{I} / \mathrm{R}$ group than that in $\mathrm{I} / \mathrm{R}$ female and $\mathrm{Ovx}+\mathrm{E}+\mathrm{I} / \mathrm{R}$ groups. This indicates that estrogen has a reno-protective effect during I/R injury (Table 2). Furthermore, serum LDH, serum CK and cardiac tissue LPO were significantly higher in Ovx group than in control female group, and in $\mathrm{Ovx}+\mathrm{I} / \mathrm{R}$ group than in all other female groups. Also, cardiac tissue antioxidant enzymes (GR, SOD and CAT) were significantly lower in Ovx group than in control female group, and in Ovx $+\mathrm{I} / \mathrm{R}$ group than in all other female groups. However, there was no significant difference between Ovx+E+I/R and I/R female groups. This indicates that ovarian hormones, especially estrogen, have a potent cardio-protective effect (Table 2).

\section{Sex differences in renal and cardiac injury markers after acute renal $I / R$ injury in rats}

Blood urea and serum creatinine were significantly higher in I/R male group than in I/R female group. Serum LDH, serum $\mathrm{CK}$, and cardiac tissue LPO were significantly higher in I/R male group than in I/R female group. Cardiac tissue antioxidant enzymes, GR, SOD and CAT, were significantly lower in the I/R male group than in I/R female group (Figure 1).

\section{Discussion}

The results obtained in the present study showed that bilateral renal I/R injury in male and female rats led to a sig- nificant rise in renal injury markers, blood urea and serum creatinine, compared to the control groups. These results are in line with Mount et al. (2012) and Chen et al. (2012). Furthermore, Kadkhodaee et al. (2009) reported that the rise of renal injury markers was dependent on the renal ischemia time, and Jung et al. (2009) found the increase in renal injury markers reached the peak 48 hours after the renal I/R injury. On the other hand, Vinodini et al. (2009) reported no change in serum urea level after renal I/R; this controversy is due to protocol differences as the rats underwent unilateral I/R, and the reperfusion period was only 90 minutes.

The deterioration in renal functions following renal $\mathrm{I} / \mathrm{R}$ injury could be explained by the generation of reactive $\mathrm{O}_{2}$ species during the reperfusion period which, in turn, have diverse cytotoxic effects, including DNA damage, protein oxidation and nitrosylation, and lipid peroxidation. Renal $\mathrm{I} / \mathrm{R}$ injury also causes endothelial dysfunction, induces apoptosis, and releases local inflammatory mediators, e.g. tumor necrosis factor-alpha (TNF- $\alpha$ ) and interleukins (IL), IL-1 and IL-6 (Chen et al. 2012).

As regard cardiac injury markers; this study showed that bilateral renal I/R led to a significant rise in serum LDH and CK levels compared to the control groups. These results are in accordance with Mahfoudh-Boussaid et al. (2012), Vaghasiya et al. (2010) and Şener et al. (2005) results. Moreover, bilateral renal I/R showed a cardiac oxidative stress injury indicated by a significant increase in the cardiac tissue LPO level, as well as a significant decrease in cardiac antioxidant enzymes, GR, SOD and CAT, levels compared to the control groups. These results are in line with Vaghasiya et al. (2010). This could be explained by the cardiac lesions following acute renal I/R injury, evidenced by the increase in cardiac tissue LPO and the decrease in cardiac tissue antioxidants. 
There is an intimate link between the renal ischemia and the heart through the activation of renin-angiotensin-aldosterone system; this effect may contribute to the hypertension as well as the renal and cardiovascular damage following renal ischemia (Minuz et al. 2002). Aldosterone has other adverse effects that can contribute to the pathophysiology of congestive heart failure. These effects include coronary and renovascular remodeling, endothelial-cell and baroreceptor dysfunction, and inhibition of myocardial norepinephrine uptake, together with reduced heart-rate variability (Weber 2001). Ang II is known to be a potent stimulator of vascular $\mathrm{O}_{2}$ free radical production, with subsequent endothelial dys-
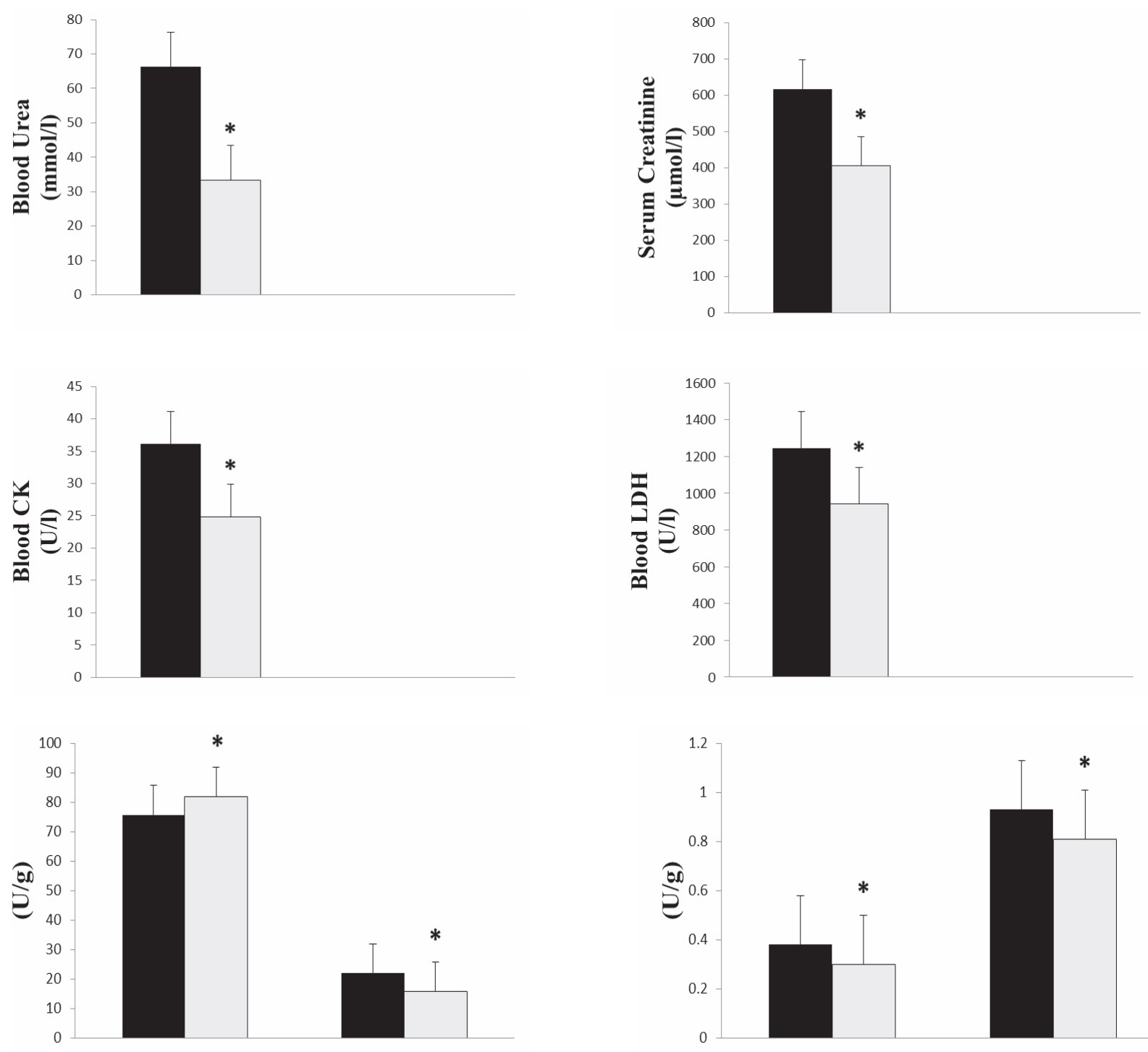

Cardiac tissue LPO Cardiac tissue SOD

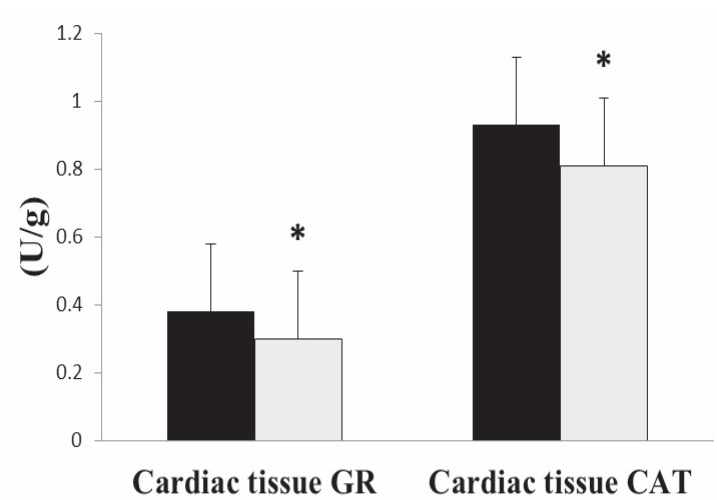

I/R males

I/R females

Figure 1. Sex differences in some renal injury markers, and cardiac injury markers after acute renal I/R injury in rats. The figure shows sex differences in some renal and cardiac injury markers after acute renal I/R injury in rats: blood urea and serum creatinine were significantly higher in I/R male group than in I/R female group. Serum LDH, serum CK, and cardiac tissue LPO were significantly higher in I/R male group than in I/R female group. Cardiac tissue antioxidant enzymes, GR, SOD and CAT, were significantly lower in the I/R male group than in I/R female group. Results expressed as mean \pm SEM. ${ }^{*}$ significant different from I/R male, $p<0.05$. I/R, ischemia reperfusion; CK, creatine kinase; LDH, lactate dehydrogenase; LPO, lipid peroxide; SOD, superoxide dismutase; GR, glutathione reductase; CAT, catalase. 
function (Himmelfarb 2005). Both Ang II and aldosterone are also involved in regulating the inflammatory process that follows renal injury. They stimulate cytokine production, inflammatory-cell adhesion, and chemotaxis which result in severe impairment of cardiac functions, apoptosis of cardiac myocytes, and increased cardiac expression of intercellular adhesion molecule 1, consistent with leukocytic infiltration of the heart and increased cardiac myeloperoxidase (MPO) activity with production of hypochlorous acid, a highly reactive chlorine species, which can oxidize a variety of molecules, including proteins, to cause tissue injury and dysfunction (Weber 2001; Vaziri 2008).

Renal I/R injury leads to attenuated antioxidant enzyme pool. During the ischemic period, ATP is catabolized to yield hypoxanthine. The hypoxic stress also triggers the conversion of NAD-reducing xanthine dehydrogenase to the oxygen radical-producing xanthine oxidase. During reperfusion, molecular oxygen is reintroduced into the tissue where it reacts with hypoxanthine and xanthine oxidase to produce a burst of superoxide $\left(\mathrm{O}_{2} \bullet^{-}\right)$and hydrogen peroxide $\left(\mathrm{H}_{2} \mathrm{O}_{2}\right)$. In the presence of electron donors e.g. $\mathrm{Fe}^{2+}$, released from myoglobin destruction, or $\mathrm{O}_{2} \bullet^{-}, \mathrm{H}_{2} \mathrm{O}_{2}$ is converted to hydroxyl radical $\left(\mathrm{OH}^{\circ}\right)$ via the Fenton reaction $\left[\mathrm{H}_{2} \mathrm{O}_{2}+\mathrm{Fe}^{2+}\right.$ $\left.\rightarrow \mathrm{OH}^{-}+\mathrm{OH}^{\bullet}+\mathrm{Fe}^{3+}\right]$ or Haber-Weiss reaction $\left[\mathrm{H}_{2} \mathrm{O}_{2}+\right.$ $\mathrm{O}_{2} \bullet^{-} \rightarrow \mathrm{OH}^{-}+\mathrm{OH}^{\bullet}+\mathrm{O}_{2}$ ]. Hydroxyl radical $\left(\mathrm{OH}^{\bullet}\right)$ is the most reactive cytotoxic radical known, it attacks and denatures the adjacent molecules such as lipids, proteins, carbohydrates, and nucleic acids (e.g. DNA), and initiates lipid peroxidation of cell membrane components and the subsequent release of substances that attract, activate, and promote the adherence of granulocytes to microvascular endothelium. The adherent granulocytes then cause further endothelial cell injury via the release of $\mathrm{O}_{2} \bullet^{-}$and various proteases (Vaziri 2008).

In the present study renal injury markers were significantly higher in the I/R male group than in the I/R female group, supporting the high mortality in the I/R male group. These results are in line with Robert et al. (2011), Rusai et al. (2011) and Hu et al. (2009).

Renal injury markers were also significantly higher in $\mathrm{Ovx}+\mathrm{I} / \mathrm{R}$ group than in both, $\mathrm{Ovx}+\mathrm{E}+\mathrm{I} / \mathrm{R}$ group and $\mathrm{I} / \mathrm{R}$ group. These results are in line with Pinheiro and Silva (2012) who reported that the renal I/R injury was exacerbated by ovariectomy. Conversely, Park and coworkers $(2004,2005)$ showed that deprivation of estrogen in female animals by ovariectomy did not affect ischemic renal injury.

In this study, there are gender differences in the renal injury after I/R, evidenced by the higher susceptibility of the kidneys of males to I/R injury than those of females, higher mortality in I/R males than in I/R females, the exacerbation of renal I/R injury after ovariectomy, and the relative improvement of renal functions after $\mathrm{I} / \mathrm{R}$ in ovariectomized females with estradiol replacement. The ovarian hormones, especially estrogen, are responsible, at least partly, for the renal protection in females. Estrogen mainly induces the antioxidant enzymes, thus preventing the oxidative stress damage following renal I/R injury. It also increases NO production causing potent vasodilatation, thus increasing the renal blood flow. Estrogen also affects the mitogen-activated protein kinases (MAPK) produced after renal I/R injury, via increasing the activation of extracellular signal-related kinase (ERK) that promotes cell survival, and decreasing the activation of p38 that promotes cell death (Park et al. 2004). Estrogen also increases the expression of heat-shock protein HSP-72 in the renal tubular cells which, in turn, mediates $\mathrm{Na}^{+} / \mathrm{K}^{+}$ATPase and is essential for maintenance of actin cytoskeletal integrity; thus preventing the time-dependent translocation of $\mathrm{Na}^{+} / \mathrm{K}^{+}$ATPase from the basolateral to the apical membranes of the proximal tubular cells following renal I/R injury (Fekete et al. 2006).

In this study serum $\mathrm{LDH}$, serum $\mathrm{CK}$ and cardiac tissue LPO were significantly higher in control male group than in control female group, and in I/R male group than in I/R female group. Also, cardiac tissue antioxidant enzymes, GR, SOD and CAT, were significantly higher in control female group than in control male group, and in I/R female group than in I/R male group. Furthermore, serum LDH, serum $\mathrm{CK}$ and cardiac tissue LPO were significantly higher in Ovx group than in control female group, and in Ovx $+\mathrm{I} / \mathrm{R}$ group than in all other female groups. Also, cardiac tissue antioxidant enzymes were significantly lower in Ovx group than in control female group, and in Ovx $+\mathrm{I} / \mathrm{R}$ group than in all other female groups. These results are in line with Barp et al. (2002) and Kim et al. (1998). On the other hand, Barp et al. (2002) found that myocardial CAT activity was not significantly different between control male and female groups. However, no other study investigated the differences in cardiac injury markers after renal I/R injury between males and females. The higher level of cardiac CAT in females than in males reported in this study could be explained by the increased activity of SOD which catalyzes the dismutation of $\mathrm{O}_{2}{ }^{-}$into $\mathrm{O}_{2}$ and $\mathrm{H}_{2} \mathrm{O}_{2}$; the accumulating $\mathrm{H}_{2} \mathrm{O}_{2}$ induces the expression of CAT (Röhrdanz and Kahl 1998). Azevedo et al. (2001) reported that CAT level in macrophages was significantly higher in female rats than in males, and ovariectomy led to significant reduction in its level. Massafra et al. (1997), as well, found that females receiving oral contraceptives showed a significant increase in the serum CAT level, indicating that sex steroids may have an antioxidant activity mediated by CAT induction.

The ovarian hormones, especially estrogen, have a significant cardio-protective effect. Estrogen decreases the cytokine production, e.g. TNF- $\alpha$, IL-1, IL-6 and IL-10, after acute injury. Estrogen also increases NO production through increased expression of inducible nitric oxide synthase (iNOS) and endothelial nitric oxide synthase (eNOS) in cardiac myocytes. NO provides cardiovascular protection 
via reducing the expression of adhesion molecules, especially $P$ selectin, and decreasing neutrophil accumulation. In addition, estrogen leads to modulation of $\mathrm{Ca}^{2+}$ influx and release, and activation of ATP-sensitive potassium channel $\left(\mathrm{K}_{\mathrm{ATP}}\right)$ channels in the cardiac mitochondria. Finally, estrogen has an anti-apoptotic effect on cardiac myocytes via decreasing caspase-3 activity (Kher et al. 2005). Estrogen, itself, acts as an antioxidant via donating hydrogen atoms from its phenolic hydroxyl group, thus terminating the peroxidation chain reaction in a way similar to vitamin E. It increases the activity of antioxidant enzymes as well, thus protects the heart from the oxidative stress which is one of the stimuli for the inflammatory cytokine production (Sotiriadou et al. 2003).

In conclusion, acute renal I/R injury causes: deterioration in renal functions in both male and female rats proved by the increase in serum urea and creatinine, cardiac lesions in both male and female rats proved by the increase in serum $\mathrm{LDH}$ and CK. These lesions are mainly due to the oxidative stress response in the form of the increase in cardiac tissue LPO, and the decrease in cardiac tissue antioxidant enzymes (GR, SOD and CAT). Female rats are more protected from the renal and cardiac lesions following acute renal I/R injury than male rats. Estrogen decreases the cardiac lesions following acute renal I/R mainly by inhibiting the oxidative stress response.

Accordingly, estrogen can be given particularly to female patients to decrease the high mortality rate that accompanies acute renal ischemic conditions. Administration of antioxidants during reperfusion injury can be beneficial to reduce the severity of IR injury through the augmentation of endogenous antioxidants. This could be a promising therapeutic approach to combat oxidative stress associated with cardiac lesions following renal I/R injury, but that requires further investigation.

\section{References}

Aebi H. (1984): Catalase in vitro. Meth. Enzymol. 105, 121-126 http://dx.doi.org/10.1016/S0076-6879(84)05016-3

Azevedo R. B., Lacava Z. G., Miyasaka C. K., Chaves S. B., Curi R. (2001): Regulation of antioxidant enzyme activities in male and female rat macrophages by sex steroids. Braz. J. Med. Biol. Res. 34, 683-687 http://dx.doi.org/10.1590/S0100-879X2001000500018

Barp J., Araújo A. S., Fernandes T. R., Rigatto K. V., Llesuy S., Belló-Klein A., Singal P. (2002): Myocardial antioxidant and oxidative stress changes due to sex hormones. Braz. J. Med. Biol. Res. 35, 1075-1081 http://dx.doi.org/10.1590/S0100-879X2002000900008

Chen G., Fu Y., Wu X. (2012): Protective effect of salvia miltiorrhiza extract against renal ischemia-reperfusion-induced injury in rats. Molecules 17, 1191-1202 http://dx.doi.org/10.3390/molecules17021191
Fekete A., Vannay A., Vér A., Rusai K., Müller V., Reusz G., Tulassay T., Szabó A. J. (2006): Sex differences in heat shock protein 72 expression and localization in rats following renal ischemia-reperfusion injury. Am. J. Physiol. Renal Physiol. 291, 806-811 http://dx.doi.org/10.1152/ajprenal.00080.2006

Flores A., Gallegos A. I., Velasco J., Mendoza F. D., Montiel C., Everardo P. M., Cruz M. E., Domínguez R. (2008): The acute effects of bilateral ovariectomy or adrenalectomy on progesterone, testosterone and estradiol serum levels depend on the surgical approach and the day of the estrous cycle when they are performed. Reprod. Biol. Endocrinol. 6, 1-7 http://dx.doi.org/10.1186/1477-7827-6-48

Goldberg D. M., Spooner R. J. (1983): Glutathione reductase: methods of enzymatic analysis. 3rd edition, pp. 45-46, Verlag Chemie Press

Himmelfarb J. (2005): Relevance of oxidative pathways in the pathophysiology of chronic kidney disease. Cardiol. Clin. 23, 319-330

http://dx.doi.org/10.1016/j.ccl.2005.03.005

Hu H., Wang G., Batteux F., Nicco C. (2009): Gender differences in the susceptibility to renal ischemia-reperfusion injury in BALB/c mice. Tohoku. J. Exp. Med. 218, 325-329 http://dx.doi.org/10.1620/tjem.218.325

Jung Y. J., Kim D. H., Lee A. S., Lee S., Kang K. P., Lee S. Y., Jang K. Y., Sung M. J., Park S. K., Kim W. (2009): Peritubular capillary preservation with COMP-angiopoietin-1 decreases ischemiareperfusion-induced acute kidney injury. Am. J. Physiol. Renal Physiol. 297, 952-960 http://dx.doi.org/10.1152/ajprenal.00064.2009

Kadkhodaee M., Golab F., Zahmatkesh M., Ghaznavi R., Hedayati M., Arab H. A., Ostad S. N., Soleimani M. (2009): Effects of different periods of renal ischemia on liver as a remote organ. World. J. Gastroenterol. 15, 1113-1118 http://dx.doi.org/10.3748/wjg.15.1113

Kelly K. J. (2003): Distant effects of experimental renal ischemia/ reperfusion injury. J. Am. Soc. Nephrol. 14, 1549-1558 http://dx.doi.org/10.1097/01.ASN.0000064946.94590.46

Kher A., Wang M., Tsai B. M., Pitcher J. M., Greenbaum E. S., Nagy R. D., Patel K. M., Wairiuko G. M., Markel T. A., Meldrum D. R. (2005): Sex differences in the myocardial inflammatory response to acute injury. Shock 23, 1-10 http://dx.doi.org/10.1097/01.shk.0000148055.12387.15

Kim Y. D., Farhat M. Y., Myers A. K., Kouretas P., DeGroot K. W., Pacquing A., Ramwell P. W., Suyderhoud J. P., Lees D. E. (1998): 17-Beta estradiol regulation of myocardial glutathione and its role in protection against myocardial stunning in dogs. J. Cardiovasc. Pharmacol. 32, 457-465 http://dx.doi.org/10.1097/00005344-199809000

Mahfoudh-Boussaid A., Zaouali M. A., Hadj-Ayed K., Miled A. H., Saidane-Mosbahi D., Rosello-Catafau J., Ben Abdennebi H. (2012): Ischemic preconditioning reduces endoplasmic reticulum stress and upregulates hypoxia inducible factor- $1 a$ in ischemic kidney: the role of nitric oxide. J. Biomed. Sci. 19, 1-8 http://dx.doi.org/10.1186/1423-0127-19-7

Massafra C., Buonocore G., Gioia D., Sargentini I., Farina G. (1997): Effects of estradiol and medroxyprogesterone-acetate 
treatment on erythrocyte antioxidant enzyme activities and malondialdehyde plasma levels in amenorrhoic women. J. Clin. Endocrinol. Metab. 82, 173-175 http://dx.doi.org/10.1210/jc.82.1.173

Metcalfe P. D., Meldrum K. K. (2006): Sex differences and the role of sex steroids in renal injury. J. Urol. 176, 15-21 http://dx.doi.org/10.1016/S0022-5347(06)00490-3

Minuz P., Patrignani P., Gaino S., Degan M., Menapace L., Tommasoli R., Seta F., Capone M. L., Tacconelli S., Palatresi S., Bencini C., Del Vecchio C., Mansueto G., Arosio E., Santonastaso C. L., Lechi A., Morganti A., Patrono C. (2002) Increased oxidative stress and platelet activation in patients with hypertension and renovascular disease. Circulation 106, 2800-2805 http://dx.doi.org/10.1161/01.CIR.0000039528.49161.E9

Moren L. G. (1977): Creatine kinase: re-examination of optimum reaction conditions. Clin. Chem. 23, 1569-1575

Mount P. F., Gleich K., Tam S., Fraser S. A., Choy S. W., Dwyer K. M., Lu B., Denderen B. V., Fingerle-Rowson G., Bucala R., Kemp B. E., Power D. A. (2012): The outcome of renal ischemiareperfusion injury is unchanged in AMPK- $\beta 1$ deficient mice. PLoS One 7, e29887 http://dx.doi.org/10.1371/journal.pone.0029887

Neugarten J. (2002): Gender and the progression of renal disease. J. Am. Soc. Nephrol. 13, 2807-2809 http://dx.doi.org/10.1097/01.ASN.0000035846.89753.D4

Nishikimi M., Rao N. A., Yagi K. (1972): The occurrence of superoxide anion in the reaction of reduced phenazine methosulphate and molecular oxygen. Biochem. Biophys. Res. Commun. 46, 849-854 http://dx.doi.org/10.1016/S0006-291X(72)80218-3

Ohkawa H., Ohishi N., Yagi K. (1979): Assay for lipid peroxidase in animal tissue by thiobarbituric acid reaction. Anal. Biochem. 95, 351-358 http://dx.doi.org/10.1016/0003-2697(79)90738-3

Ostadal B., Netuka I., Maly J., Besik J., Ostadalova I. (2009): Gender differences in cardiac ischemic injury and protection: experimental aspects. Exp. Biol. Med. (Maywood). 234, 1011-1019 http://dx.doi.org/10.3181/0812-MR-362

Park K. M., Cho H. J., Bonventre J. V. (2005): Orchiectomy reduces susceptibility to renal ischemic injury: a role for heat shock proteins. Biochem. Biophys. Res. Commun. 328, 312-317 http://dx.doi.org/10.1016/j.bbrc.2004.12.177

Park K. M., Kim J. I., Ahn Y., Bonventre A. J., Bonventre J. V. (2004): Testosterone is responsible for enhanced susceptibility of males to ischemic renal injury. J. Biol. Chem. 279, 52282-52292 http://dx.doi.org/10.1074/jbc.M407629200

Pinheiro S. V., Silva A. C. (2012): Angiotensin converting enzyme 2, angiotensin-(1-7), and receptor mas axis in the kidney. Int. J. Hypertens. 2012, 1-8 http://dx.doi.org/10.1155/2012/414128

Rechsteiner M. C. (1970): Drosophila lactate dehydrogenase: partial purification and characterization. J. Insect. Physiol. 16, 957-977 http://dx.doi.org/10.1016/0022-1910(70)90226-X
Robert R., Ghazali D. A., Favreau F., Mauco G., Hauet T., Goujon J. M. (2011): Gender difference and sex hormone production in rodent renal ischemia reperfusion injury and repair. J. Inflamm. (Lond). 8, 14-22 http://dx.doi.org/10.1186/1476-9255-8-14

Röhrdanz E., Kahl R. (1998): Alterations of antioxidant enzyme expression in response to hydrogen peroxide. Free Radic. Biol. Med. 24, 27-38 http://dx.doi.org/10.1016/S0891-5849(97)00159-7

Rusai K., Prókai A., Szebeni B., Mészáros K., Fekete A., Szalay B., Vannay Á., Degrell P., Müller V., Tulassay T., Szabó A.J. (2011): Gender differences in serum and glucocorticoid regulated kinase-1 (SGK-1) expression during renal ischemia/reperfusion injury. Cell. Physiol. Biochem. 27, 727-738 http://dx.doi.org/10.1159/000330081

Sener G., Sener E., Sehirli O., Oğünç A. V., Cetinel S., Gedik N., Sakarcan A. (2005): Ginkgo biloba extract ameliorates ischemia reperfusion-induced renal injury in rats. Pharmacol. Res. 52, 216-222

http://dx.doi.org/10.1016/j.phrs.2005.03.006

Shivanand P. (2010): A review on pathology of myocardial ischemia and various types of novel biomarkers. Int. J. Pharm. Sci. 2, 35-39

Sirotković-Skerlev M., Plestina S., Bilić I., Kovac Z. (2006): Pathophysiology of ischaemia-reperfusion injury. Lijec. Vjesn. 128, 87-95 (in Croatian)

Sotiriadou S., Kyparos A., Mougios V., Trontzos C., Sidiras G., Matziari C. (2003): Estrogen effect on some enzymes in female rats after downhill running. Physiol. Res. 52, 743-748

Vaghasiya J. D., Sheth N. R., Bhalodia Y. S., Jivani N. P. (2010): Exaggerated liver injury induced by renal ischemia reperfusion in diabetes: Effect of exenatide. Saudi J. Gastroenterol. 16, 174-180 http://dx.doi.org/10.4103/1319-3767.65187

Vaziri N. D. (2008): Causal link between oxidative stress, inflammation, and hypertension. Iran. J. Kidney Dis. 2, 1-10

Vinodini N. A., Tripathi Y., Raghuveer C. V. (2009): Effect of 60 minutes of renal ischemia followed by 10 and 90 minutes of reperfusion. J. Chin. Clin. Med. 4, 121-125

Weber K. T. (2001): Aldosterone in congestive heart failure. N. Engl. J. Med. 345, 1689-1697 http://dx.doi.org/10.1056/NEJMra000050

White L. E., Hassoun H. T. (2012): Inflammatory mechanisms of organ crosstalk during ischemic acute kidney injury. Int. J. Nephrol. 2012

Young D. S. (2001): Effects of Disease on Clinical Laboratory Tests. 4th edition, pp. 67-69, American Association for Clinical Chemistry Press

Yu P. L., Wu C. I., Lee T. S., Pan W. H., Wang P. S., Wang S. W. (2009): Attenuation of estradiol on the reduction of striatal dopamine by amphetamine in ovariectomized rats. J. Cell. Biochem. 108, 1318-1324

http://dx.doi.org/10.1002/jcb.22361

Received: November 13, 2012

Final version accepted: February 18, 2013 